\title{
Effects of food restriction and pregnancy on the expression of insulin-like growth factors-I and -II in tissues from guinea pigs
}

\author{
H Olausson and A Sohlström \\ Department of Biomedicine and Surgery, Division of Nutrition, Linköping University, S-581 85 Linköping, Sweden \\ (Requests for offprints should be addressed to H Olausson; Email: hanna.olausson@ibk.liu.se)
}

\begin{abstract}
The insulin-like growth factor (IGF) system is subjected to pregnancy-associated changes in the circulation and is suggested to be of importance for partitioning of nutrients between the mother and the foetus. Interestingly, maternal undernutrition alters the pregnancy-associated changes, with possible adverse consequences for the mother and the foetus. However, it is not known how malnutrition and pregnancy alter the expression of mRNA for IGFs locally in different tissues. The aims of this study were to investigate where IGF-I and IGF-II are expressed in guinea pigs and how this expression is altered during food restriction and pregnancy. Ad libitum-fed and foodrestricted (fed $70 \%$ of the ad libitum-fed intake four weeks before pregnancy and throughout the study) guinea pigs were mated. On day 40 of pregnancy and on the corresponding day for virginal females the animals were killed. mRNA for IGF-I and IGF-II was analysed in various
\end{abstract}

organs/tissues by solution hybridisation. mRNA for IGF-I was expressed in high amounts in uterus, liver and adipose tissues. The expression was not affected by food restriction, but was increased in liver and adipose tissue and decreased in uterus by pregnancy. mRNA for IGF-II was expressed in high amounts in the placenta and liver. In the placenta the expression was decreased by food restriction. Pregnancy increased the levels of mRNA for IGF-II in the liver. Food-restricted dams had smaller foetuses and placentas. In conclusion, this study indicates an important role for the adipose tissue during gestation, not only as an energy store but also as an endocrine tissue expressing IGF-I. The decreased expression of IGF-II in the placenta due to food restriction is suggested to have adverse effects on placental structure and function.

Journal of Endocrinology (2003) 179, 437-445

\section{Introduction}

In order to be able to provide the foetus and the newborn with sufficient energy and nutrients, the pregnant mother undergoes a number of physiological, metabolic and endocrine adaptations (Prentice et al. 1995). Changes in the insulin-like growth factor (IGF) system is one of these. The IGF system has been suggested to influence the substrate supply to the foetus, and hence its growth, by modulating maternal metabolism and placental function (Owens 1991). Such a role may be of particular significance when access to energy and nutrients is limited.

The IGF system includes the ligands IGF-I and -II, six characterised high affinity binding proteins (IGFBP-1 to -6) and three cell surface receptors (type 1 IGF receptor, type 2 IGF receptor and insulin receptor) (Jones \& Clemmons 1995). IGF-I and -II are growth factors responsible for inducing proliferation, differentiation and metabolic changes in a variety of cell types (Jones \& Clemmons 1995). IGF-I and -II are associated to a great extent with IGFBPs (Jones \& Clemmons 1995), and are able to affect the bioavailability and the action of IGFs (Clemmons 1998). Growth hormone (GH) (Butler \& LeRoith 2001) and nutrition (Thissen et al. 1994) are the main regulators of the IGF system. While the polypeptides IGF-I and -II, the IGFBPs and the receptors are synthesised in many tissues (Cohick \& Clemmons 1993, Jones \& Clemmons 1995), the liver is thought to be the major contributor to the circulatory levels of IGFs (Cohick \& Clemmons 1993, Butler \& LeRoith 2001, Ohlsson et al. 2000).

During pregnancy, maternal plasma levels of IGF-I increase early in most species (Wilson et al. 1982, Gargosky et al. 1990, Donovan et al. 1991, Hills et al. 1996, Nason et al. 1996, Sohlström et al. 1998b). The abundance of circulatory IGF-II increases in some species (Nason et al. 1996), including humans (Wilson et al. 1982, Gargosky et al. 1990), but remains unchanged in others (Donovan et al. 1991, Sohlström et al. 1998b). On the one hand, results from rat studies indicate that maternal serum IGF-I targets the mother's own anabolism and substrate retention rather than the foetus (Gargosky et al. 1991, 
Monaco \& Donovan 1996). On the other hand, in humans (Hall et al. 1986, Holmes et al. 1998) and guinea pigs (Sohlström et al. 2001) maternal IGF-I seems to be associated with foetal and placental growth. Maternal plasma levels of IGF-II have been shown to promote the structural development of the placenta (Roberts et al. 2001b) and IGF-II produced by the trophoblasts has been suggested to be important for implantation and placentation (Hamilton et al. 1998, Han et al. 1999, Rutanen 2000). However, maternal undernutrition alters these pregnancy-associated changes in the IGF system, with possible adverse consequences for the mother, the placenta and the foetus (Sohlström et al. 1998b, Roberts et al. 2001b).

Studies on the role of maternal IGFs during pregnancy have so far mainly been focused on plasma levels and the endocrine action of these peptides. Recently, it was shown that genetically modified mice with inactivated liverderived IGF-I had dramatically decreased IGF-I levels in plasma without any impairment of postnatal growth, indicating that non-hepatic, autocrine/paracrine-acting IGF-I is one main determinant of postnatal growth (Sjögren et al. 1999, Ohlsson et al. 2000, Butler \& LeRoith 2001). However, these mice had increased serum levels of $\mathrm{GH}$, since the circulating IGF-I normally exerts negative feedback regulation on GH secretion (Sjögren et al. 1999). Thus, the tissue-specific expression of IGFs and their autocrine/paracrine actions are of great importance for growth and metabolism. It is possible that non-hepatic IGFs may also contribute to the circulating concentrations of IGFs.

In this study the expression of mRNA for IGF-I and -II was studied in various tissues in ad libitum-fed and foodrestricted guinea pigs in midpregnancy and on the corresponding day for virginal females. Guinea pigs (Daughaday et al. 1986), like humans (Gargosky et al. 1990) but unlike rodents (Donovan et al. 1989), express substantial amounts of IGF-II in adult life and have a progressive increase in circulatory IGF-I during pregnancy (Sohlström et al. 1998b).

The aims of this study were to investigate where IGF-I and IGF-II are expressed in guinea pigs and how this expression is altered by food restriction and pregnancy.

\section{Materials and Methods}

Nulliparous female Dunkin-Hartley guinea pigs $(n=34)$, 2-3 months old and weighing $475 \pm 26 \mathrm{~g}$ at arrival, were obtained from Charles River Laboratories, Sulzfeid, Germany. The animals were housed individually in a room with a $12 \mathrm{~h}$ light:12 h darkness cycle and a temperature of $21^{\circ} \mathrm{C}$. They were fed with a guinea pig diet from Special Diet Services, Witham, Essex, UK. The animals had free access to water. One week after arrival and four weeks before mating, guinea pigs were randomly divided into two groups, one that had feed available ad libitum and one that was subjected to food restriction. Food intake and body weight were measured three times a week. Foodrestricted animals were given $70 \%$ of the average food intake during the previous 2 or 3 days of the ad libitum-fed animals throughout the study. During the four weeks before mating it was noticed however that the ad libitumfed animals including those being mated later had a stable food intake. Thus, the food ration of the food-restricted dams was set to $21 \mathrm{~g}$ every day and for the food-restricted virginal animals this ration continued throughout the study. For the pregnant animals the food intake increased during pregnancy. After four weeks of nutritional control, half of the animals in each dietary group were mated. A female in oestrus was put with a male overnight, and the female was regarded as pregnant when a vaginal copulatory plug was found the following morning. This day was regarded as day 1 of gestation. The following four groups were investigated and their mean body weight in grams at day 1 of gestation and on the corresponding day for virginal animals are shown within parentheses: virginal/ad libitumfed $\quad(692 \pm 42), \quad$ virginal/food-restricted $\quad(501 \pm 16)$, pregnant/ad libitum-fed (580 \pm 44$)$ and pregnant/foodrestricted $(538 \pm 36)$. Since pregnant animals also took part as controls in another study (Sohlström et al. 2001), osmotic mini-pumps (Alzet, Model 2002, Scanbur BK AB, Sollentuna, Sweden) filled with $240 \mu \mathrm{l} 0 \cdot 1 \mathrm{~mol} / 1$ acetic acid were placed s.c. on their backs at day 20 of gestation after the animals were anaesthetised with injections of ketamine, $25 \mathrm{mg} / \mathrm{kg}$ i.m. (Pfizer) and xylocaine, $4 \mathrm{mg} / \mathrm{kg}$ s.c. (Bayer $\mathrm{AB}$, Leverkusen, Germany), and locally with a s.c. injection of lidocaine (Astra Zeneca). The virginal guinea pigs were not subjected to this procedure. On day 40 of pregnancy or on the corresponding day in virginal females, the animals were sedated in $\mathrm{CO}_{2}$ for $15 \mathrm{~s}$ and then killed by an intracardiac overdose of pentobarbital sodium $60 \mathrm{mg} / \mathrm{kg}$ (Astra Zeneca). Immediately after death, 5-10 ml blood were collected by cardiac puncture into chilled plastic tubes containing 10 $\mathrm{IU} / \mathrm{ml}$ heparin (Lövens Läkemedel, Malmö, Sweden) and $500 \mathrm{IU} / \mathrm{ml}$ aprotinin (Bayer $\mathrm{AB}$ ), and the animals were thereafter put on ice. The tubes were stored on ice until centrifugation. Plasma was harvested and frozen at $-20{ }^{\circ} \mathrm{C}$ until analysis. The following tissues and organs were removed from the carcass and immediately weighed: individual foetuses and placentas, liver, spleen, muscle biceps, muscle triceps, and parametrial and interscapular adipose tissues. Tissues and organs were immediately snap frozen on dry ice and stored at $-80{ }^{\circ} \mathrm{C}$ until analyses of mRNA. This protocol was approved by the Stockholm Ethical Committee for Experiments in Animals, Sweden. The animal care conformed to the European Convention for Protection of Vertebrates used for Experimental and Other Scientific Purposes published by the Council of Europe 1985 (no. 123), Strasbourg. 


\section{Blood analyses}

IGF-I and -II were measured by radioimmunoassay (RIA) as previously reported for guinea pigs (Conlon et al. 1995, Sohlström et al. 1998a). Plasma was acidified to $\mathrm{pH} 2.5$ and then fractionated by size exclusion high performance liquid chromatography at $\mathrm{pH} 2 \cdot 5$. Individual plasma samples were extracted with freon according to Owens et al. (1990) and then injected onto a Protein-Pak 125 exclusion column (Waters/Millipore, Lane Cove, NSW, Australia). Triplicate aliquots were neutralised with Trisbase and their IGF-I and IGF-II content measured by specific RIAs. Recombinant human IGF-I and IGF-II (GroPep Pty. Ltd, Adelaide, Australia) were used for preparation of radioligands and standards for their respective RIAs. In the IGF-I RIA, a rabbit anti-human (h) IGF-I (MAC 89/1), having a cross-reactivity with hIGF-II of $<1 \%$, was used at a final dilution of 1:60 000 . In the IGF-II RIA, a mouse anti-rat IGF-II monoclonal antibody (IGF S1-F2) was used, with a cross-reactivity with hIGF-I of $2 \cdot 5 \%$ at $1 \mathrm{ng} /$ reaction tube and $100 \%$ to human IGF-II (Conlon et al. 1995). Guinea pig IGF-I (Bell et al. 1990) and IGF-II (Levinovitz et al. 1992) are identical to human IGF-I and -II. The intra- and interassay coefficients of variation were, respectively, $5.5 \%$ and $6 \cdot 9 \%$ for IGF-I and $7 \cdot 8 \%$ and $10 \cdot 1 \%$ for IGF-II.

\section{Tissue analyses}

All maternal tissues were analysed and one placenta from each dam was randomly selected.

\section{Total nucleic acid (TNA) preparation}

TNA was prepared as described earlier (Durnam \& Palmiter 1983). Tissues were homogenised in $4 \mathrm{ml} \mathrm{SET}$ buffer $(1 \%(\mathrm{w} / \mathrm{v})$ sodium dodecyl sulphate (SDS), $20 \mathrm{mM}$ Tris- $\mathrm{HCl}(\mathrm{pH} 7 \cdot 5)$, and $10 \mathrm{mM}$ EDTA) and digested with proteinase $\mathrm{K}(800 \mu \mathrm{g})$ for $45 \mathrm{~min}$ at $45^{\circ} \mathrm{C}$. TNA was extracted by phenol-chloroform, followed by precipitation by adding two volumes of ethanol. The concentrations of the nucleic acids in TNA that were sampled were measured spectrophotometrically.

\section{Solution hybridisation}

Quantification of mRNA for IGF-I and IGF-II was performed using RNA probes labelled with ${ }^{35}$ S-UTP (Amersham Inernational plc, Amersham, Bucks, UK) (Durnam \& Palmiter 1983). cDNA for IGF-I and -II probes was cloned separately into expression vector pGEM-T (Promega, Madison, WI, USA), allowing in vitro synthesis (Melton et al. 1984), using SP6 and T7 RNA polymerases. cDNA for IGF-I and -II was kindly obtained from G Bell (Departments of Biochemistry and Molecular Biology and Medicine, University of Chicago, IL, USA) and B Peterkofsky (Laboratory of Biochemistry, National Cancer Institute, Bethesda, MD, USA). Each vector was sequenced to assure significant alignment of mRNA for IGF-I and IGF-II in guinea pig and 100\% homology was obtained. mRNA probes were hybridised for $16-18 \mathrm{~h}$ at $70{ }^{\circ} \mathrm{C}$ with samples of isolated TNA. Hybridised probes were protected from RNase digestion and precipitated by addition of trichloroacetic acid $(6 \mathrm{M})$ and collected after filtration on glass fibre filters (Whatman GF/C, Maidstone, Kent, UK). The radioactivity on the filters was counted in a scintillation counter. Hybridisation signals from each sample were compared with a standard curve of known amounts of in vitro synthesised mRNA (Durnam \& Palmiter 1983, Möller et al. 1991). Each sample was analysed in duplicate.

\section{Statistical analyses}

Results are presented as means \pm standard deviation and were considered statistically significant when $P<0 \cdot 05$. The effects of food restriction in utero on the number of foetuses and on foetal and placental weight were assessed using Student's unpaired t-test. Differences between groups regarding expression of mRNA for IGF-I and -II in various tissues, plasma levels of IGF-I and -II, body weight, body weight gain, and tissue and organ weights were analysed by ANOVA with nutrition (ad libitum-fed versus food-restricted) and reproductive status (virginal versus pregnant) as components of variation. When interactions were found, planned comparisons were made to assess differences between (1) virginal/ad libitum-fed and virginal/food-restricted, (2) virginal/ad libitum-fed and pregnant/ad libitum-fed, (3) virginal/food-restricted and pregnant/food-restricted and (4) pregnant/ad libitum-fed and pregnant/food-restricted. Levene's test for equal variances was performed and found to be significant for the expression of mRNA for IGF-I in interscapular adipose tissue and uterus, and for the expression of mRNA for IGF-II in uterus. Differences between the groups in those cases were assessed by the Mann-Whitney $U$ test.

\section{Results}

$m R N A$ for IGF-I in tissues from virginal and pregnant dams

mRNA for IGF-I was expressed in all tissues being analysed from virginal females and the expression was most pronounced in the uterus, liver and parametrial and interscapular adipose tissues (Fig. 1). Food restriction had no effect on the expression of mRNA for IGF-I except in the spleen, where the relatively small expression of IGF-I mRNA was increased. In pregnant animals the expression of mRNA for IGF-I was approximately doubled in the liver, parametrial and interscapular adipose tissues as compared with virginal counterparts, regardless of nutritional 


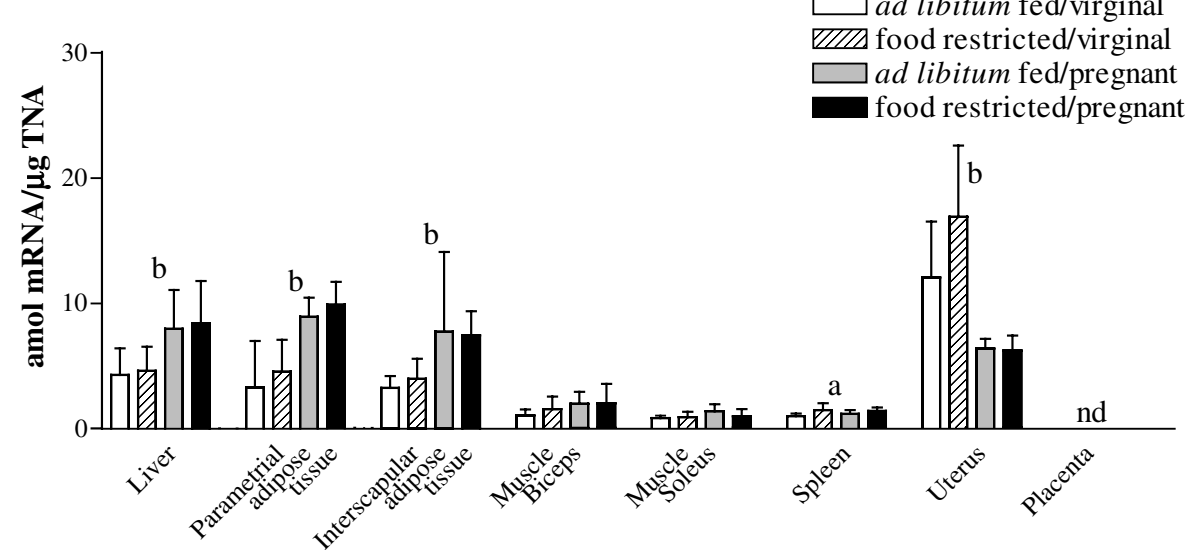

Figure 1 Expression of mRNA for IGF-I in various tissues and organs from virginal and pregnant guinea pigs. a, significant effect $(P<0.05)$ of nutrition; b, significant effect $(P<0.05)$ of pregnancy; nd, non detectable levels of mRNA for IGF-I.

status. However, in the uterus of the pregnant dams, the expression of mRNA for IGF-I was approximately half of that for the virginal dams. No mRNA for IGF-I was detected in the placenta.

\section{$m R N A$ for IGF-II in tissues from virginal and pregnant dams}

mRNA for IGF-II was expressed in all tissues being analysed from virginal and pregnant females, except in the soleus muscle (Fig. 2), and the expression was highest in the placenta and liver. Food restriction decreased the expression of mRNA for IGF-II in the placenta to $76 \%$ of that for ad libitum-fed dams. However, in the parametrial adipose tissue the expression was slightly increased by food restriction. In pregnant animals the expression of mRNA for IGF-II was doubled in the liver and increased to a small extent in the parametrial adipose tissue. Food restriction increased the expression of mRNA for IGF-II in the interscapular adipose tissue in virginal animals, but no such effect was seen in pregnant dams.

\section{Circulatory IGF-I and $-I I$}

Food restriction decreased circulatory plasma levels of IGF-I in both virginal and pregnant animals as compared with their ad libitum-fed counterparts. Both ad libitum-fed and food-restricted pregnant dams had twice as high circulatory levels of IGF-I as their virginal counterparts (Table 1). The plasma levels of IGF-II were also decreased by food restriction in both virginal and pregnant animals as compared with their ad libitum-fed counterparts. Pregnant ad libitum-fed animals had lower plasma levels of IGF-II

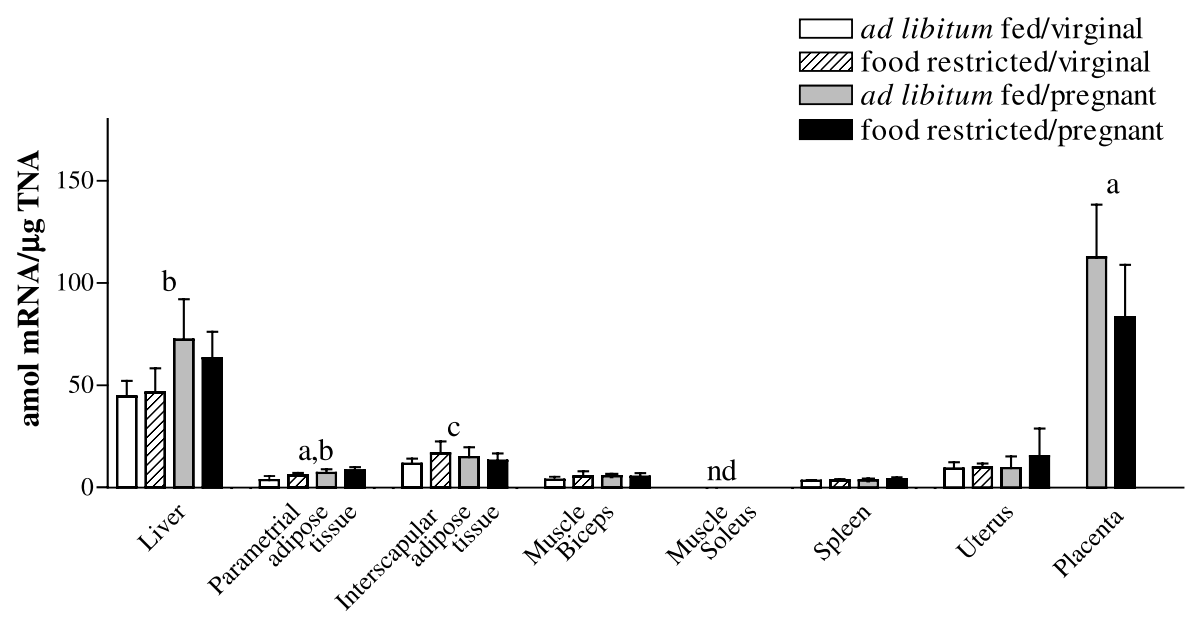

Figure 2 Expression of mRNA for IGF-II in various tissues and organs from virginal and pregnant guinea pigs. a, significant effect $(P<0.05)$ of nutrition; $b$, significant effect $(P<0.05)$ of pregnancy; $C$, interaction between nutrition and pregnancy; nd, non detectable levels of mRNA for IGF-II. 
Table 1 Number of dams, reproductive outcome, plasma levels of IGF-I and -II, body weight, tissue and organ weights in virginal and pregnant dams in the absence or the presence of food restriction. Values are means \pm standard deviation

\begin{tabular}{|c|c|c|c|c|}
\hline & Virginal & & Pregnant & \\
\hline & Ad libitum-fed & Food-restricted & Ad libitum-fed & Food-restricted \\
\hline Number of dams & 5 & 10 & 7 & 12 \\
\hline Number of foetuses/dam ${ }^{\mathrm{a}}$ & - & - & $3 \cdot 7 \pm 0 \cdot 5$ & $2 \cdot 7 \pm 0.5$ \\
\hline Foetal weight $(\mathrm{g})^{\mathrm{a}}$ & - & - & $9 \cdot 81 \pm 1 \cdot 18$ & $8 \cdot 37 \pm 1 \cdot 05$ \\
\hline Plasma IGF-I (ng/ml $)^{a, b}$ & $312 \pm 97$ & $139 \pm 81$ & $612 \pm 173$ & $283 \pm 143$ \\
\hline Plasma IGF-II $(\mathrm{ng} / \mathrm{ml})^{\mathrm{a}, \mathrm{b}, \mathrm{c}, \mathrm{d}, \mathrm{g}}$ & $1149 \pm 256$ & $500 \pm 270$ & $564 \pm 377$ & $355 \pm 181$ \\
\hline Body weight at arrival ${ }^{\mathrm{c}, \mathrm{d}, \mathrm{e}, \mathrm{f}, \mathrm{g}}$ & $496 \pm 15$ & $462 \pm 14$ & $454 \pm 10$ & $489 \pm 30$ \\
\hline Body weight at day 1 of gestation ${ }^{1, a, b, c, d, e, f, g}$ & $692 \pm 42$ & $502 \pm 16$ & $580 \pm 44$ & $538 \pm 36$ \\
\hline Body weight at day 40 of gestation $^{1, a, b, c, d, e, f}$ & $768 \pm 48$ & $575 \pm 26$ & $775 \pm 45$ & $644 \pm 28$ \\
\hline Body weight gain arrival-day $1^{2, a, b, c, d, f, g}$ & $196 \pm 42$ & $40 \pm 23$ & $126 \pm 40$ & $50 \pm 27$ \\
\hline Bodyweight gain day 1 -day $40^{3, a, b, c, e, f, g}$ & $76 \pm 22$ & $73 \pm 18$ & $196 \pm 26$ & $106 \pm 27$ \\
\hline Parametrial adipose tissue ( $\%$ of net body weight $)^{4, a, c, d, f}$ & $0 \cdot 69 \pm 0 \cdot 15$ & $0 \cdot 19 \pm 0 \cdot 07$ & $0 \cdot 60 \pm 0.09$ & $0 \cdot 26 \pm 0 \cdot 11$ \\
\hline Interscapular adipose tissue (\% of net body weight $)^{4, a}$ & $1 \cdot 34 \pm 0 \cdot 08$ & $0 \cdot 76 \pm 0 \cdot 22$ & $1 \cdot 40 \pm 0 \cdot 22$ & $0 \cdot 65 \pm 0 \cdot 21$ \\
\hline Liver (\% of net body weight $)^{4}$ & $3 \cdot 09 \pm 0 \cdot 23$ & $3 \cdot 10 \pm 0 \cdot 37$ & $3 \cdot 28 \pm 0 \cdot 35$ & $2 \cdot 98 \pm 0 \cdot 28$ \\
\hline Muscle biceps (\% of net body weight $)^{4, a, b, c, d, g}$ & $0.05 \pm 0.01$ & $0.06 \pm 0.01$ & $0.06 \pm 0.01$ & $0 \cdot 06 \pm 0 \cdot 01$ \\
\hline Muscle soleus (\% of net body weight $)^{4, a, c, d, g, e}$ & $0.27 \pm 0.03$ & $0 \cdot 36 \pm 0.04$ & $0.33 \pm 0 \cdot 02$ & $0.33 \pm 0.03$ \\
\hline Spleen (\% of net body weight $)^{4, b}$ & $0 \cdot 13 \pm 0.01$ & $0 \cdot 12 \pm 0.02$ & $0 \cdot 12 \pm 0 \cdot 01$ & $0 \cdot 10 \pm 0 \cdot 02$ \\
\hline Placental weight $(\mathrm{g})^{\mathrm{a}}$ & - & - & $2 \cdot 20 \pm 0 \cdot 18$ & $1 \cdot 96 \pm 0 \cdot 24$ \\
\hline
\end{tabular}

${ }^{1}$ Body weight at day 1 and day 40 of gestation or on the corresponding day for virginal animals. ${ }^{2}$ Body weight at day 1 of gestation (or on the corresponding day for virginal animals) minus body weight at the day of arrival. ${ }^{3}$ Body weight at day 40 of gestation minus the weight on day 1 of gestation (or on the corresponding days for virginal animals). ${ }^{4} \mathrm{Net}$ body weight is the maternal body weight at day 40 of gestation (or on the corresponding day for virginal animals) minus weight of placenta and foetuses.

${ }^{a}$ Significant effect of nutrition $(P<0 \cdot 05)$ as assessed by ANOVA. ${ }^{b}$ Significant effect of pregnancy $(P<0 \cdot 05)$ as assessed by ANOVA. ${ }^{\mathrm{C}}$ Interaction between nutrition and reproductive status $(P<0 \cdot 05)$ as assessed by ANOVA. ${ }^{\mathrm{d}}$ Significant difference between virginal/ad libitum-fed and virginal/food-restricted $(P<0 \cdot 05)$ animals as assessed by planned comparison. e Significant difference between virginal/food-restricted and pregnant/food-restricted $(P<0 \cdot 05)$ animals as assessed by planned comparison. 'Significant difference between pregnant/ad libitum-fed and pregnant/food-restricted $(P<0 \cdot 05)$ animals as assessed by planned comparison. 'Significant difference between virginal/ad libitum-fed and pregnant/ad libitum-fed $(P<0 \cdot 05)$ animals as assessed by planned comparison.

than their virginal counterparts, while no such difference was observed in pregnant and virginal food-restricted dams.

\section{Reproductive outcome, body weight and tissue and organ} weights

Food restriction reduced litter size, foetal weight and placental weight (Table 1). Body weight gain was also affected by food restriction; however this was only evident during the first weeks. Thereafter, only the pregnant food-restricted dams gained less weight as compared with their ad libitum-fed counterparts (Table 1). Food-restricted animals had less body fat and more lean tissue relative to their net body weight compared with ad libitum-fed controls (Table 1). Furthermore, food-restricted pregnant dams tended to have more parametrial adipose tissue relative to net body weight than their virginal counterparts $(P=0 \cdot 092)$.

\section{Discussion}

This study showed that in guinea pigs mRNA for IGF-I is expressed in the highest amounts in the uterus, liver and adipose tissues. The expression of IGF-I in these tissues was not affected by food restriction, but it was significantly increased in the liver and adipose tissues and decreased in the uterus in pregnant animals. The results indicate a potential endocrine function for adipose tissue during gestation. mRNA for IGF-II was highly expressed in the liver and placenta. Food restriction decreased the expression of mRNA for IGF-II in the placenta, whereas pregnant animals had a higher expression in the liver. The decreased expression of IGF-II in the placenta in undernourished dams may have adverse effects on placental size, structure and function.

The animals in this study were studied on day 40 of pregnancy, which is about midgestation as the length of gestation in guinea pigs is around 70 days. Plasma levels of IGF-I increase progressively during the first half of pregnancy in guinea pigs, and although they do not decrease during the last trimester as in rodents, the increase is modest at the end of pregnancy (Sohlström et al. 1998b). Therefore, we assume that the expression of mRNA for IGFs was measured at a time during pregnancy when it was at the highest levels and also at a time when the major growth of the placenta was occurring (Saintonge \& Rosso 1983). As shown previously in rats, chronic food restriction affects weight gain primarily at an early stage (Sohlström et al. 1994). The metabolism of the animal probably adapts to the decreased food intake by lowering the energy needs 
thereby saving energy for growth. This is probably why food restriction is shown to affect weight gain during the time before mating, but not during the last 40 days of the study. The fact that food-restricted animals had less adiposity at day 40 of gestation or on the corresponding day for the virginal animals confirmed the fact that these animals were affected by the low food intake.

Our results showed that non-hepatic tissues, particularly adipose tissues in guinea pigs, expressed as high amounts of mRNA for IGF-I as the liver. This has previously been observed in pigs (Coleman et al. 1994), rats (Peter et al. 1993) and humans (Möller et al. 1991, Peter et al. 1993), but is in contrast to findings in rats, where the liver has been shown to be the major site of expression (Möller et al. 1991). Considering the size of adipose tissue as compared with the liver, this tissue may contribute substantially to the circulating pool of IGF-I. The uterus also expressed high levels of mRNA for IGF-I. Previous studies in pregnant rats (Correia-Da-Silva et al. 1999) and pigs (Sterle et al. 1998) also showed an expression of mRNA for IGF-I in uterus, although it was not compared with other tissues besides the placenta. Consistent with our results, low levels or no expression of mRNA for IGF-I have been detected in the placenta in guinea pigs (Han et al. 1999) and rats (Möller et al. 1991). The human placenta expresses mRNA for IGF-I, although the level of the expression is dependent on the trimester of pregnancy and the site of the placenta that is analysed (Han et al. 1996).

Food restriction did not affect the expression of mRNA for IGF-I in most of the tissues that were analysed, although the plasma levels of IGF-I were decreased. This is consistent with the finding of Monaco and Donovan (1996), but in contrast to Muaku et al. (1995) and Straus and Takemoto (1991) where food restriction during gestation lowered both the plasma levels and the expression of IGF-I in the liver in rats. However, in the latter two studies the type of food restriction was different, since a very low protein diet and an extreme energy restriction were used (Straus \& Takemoto 1991, Muaku et al. 1995). Based on the findings of Monaco and Donovan (1996) and our results, we suggest that the transcription is not affected by a moderate general food restriction which primarily has low energy content and a mild protein restriction. Regulation of the plasma levels of IGF-I in food-restricted animals probably occurs posttranscriptionally, such as by altered mRNA stability, altered translation, or altered profile of the IGFBPs. Food-restricted guinea pig dams have previously been shown to have a more pronounced shift of IGF-I binding activity from higher (IGFBP-3) to lower (IGFBP-1 and IGFBP-2) molecular weight binding proteins as compared with ad libitum-fed controls (Sohlström et al. 1998b). Such a change would increase the clearance of plasma IGF-I (Bastian et al. 1993) and result in lower levels of plasma IGF. In pregnant guinea pigs, the profile of binding proteins is relatively stable until late in pregnancy
(Sohlström et al. 1998b). Furthermore, guinea pigs do not appear to have any protease activity against IGFBP-3 during pregnancy (Sohlström et al. 1998b).

In pregnant dams the expression of mRNA for IGF-I was doubled in the liver, which confirms findings of Grant et al. (P A Grant, K L Kind, C T Roberts, A Sohlström, J A Owens \& P C Owens, personal communication). Interestingly, the expression of mRNA for IGF-I in adipose tissues and the plasma levels of IGF-I were also doubled compared with virginal counterparts, regardless of dietary group. This may indicate that adipose tissue, together with the liver, is responsible for the increased plasma levels of IGF-I seen during pregnancy. This has been suggested earlier, but was based on results from in vitro studies of human adipocytes (Wabitsch et al. 2000).

Our results showed that the placenta expressed even higher levels of mRNA for IGF-II than the liver. This is consistent with findings in humans (Möller et al. 1991) and pigs (Sterle et al. 1998). Interestingly, Sterle et al. (1998) suggested that in pigs, IGF-II synthesis by the placenta may exert a negative feedback on the IGF-I expression in the uterus. This may also be true for guinea pigs, as the levels of IGF-I expression in the uterus were markedly decreased in pregnant as compared with virginal animals in the present study. Another similarity to data presented by Sterle et al. (1998) is the expression of mRNA for IGF-II in the uterus. They state that studies of the pregnant uterus endometrium should be interpreted with caution, as there may be a placental contamination. However, in our study the uterus from virginal animals also expressed mRNA for IGF-II. Thus, the expression in the uterus in the present study is not thought to be due to placental contamination.

Food restriction did not affect the expression of mRNA for IGF-II in most tissues, with the exception of the placenta and the parametrial adipose depot. In agreement with our results, Leaman et al. (1990) showed that food deprivation did not affect the expression of mRNA for IGF-II in the muscle and liver of adult swine. The fact that the food-restricted animals in our study had lower plasma levels of IGF-II than the ad libitum-fed animals suggests that the expression of IGF-II is not regulated at the transcriptional level, but rather by post-transcriptional events, as is the case for IGF-I. In general, the circulatory levels of IGF-II are less affected by malnutrition than those of IGF-I. In studies where humans and guinea pigs have been subjected to short acute fasting, no reduction or minor reductions in IGF-II have been shown (Davenport et al. 1988, Sohlström et al. 1998a). However, chronic food restriction decreases IGF-II levels in plasma in guinea pigs (Sohlström et al. 1998a,b). Similarly, severely malnourished children (Soliman et al. 1986) and severely ill patients (Davies et al. 1991) have reduced IGF-II concentrations in plasma.

In contrast to most other tissues in the pregnant guinea pig, food restriction decreased the expression of mRNA for IGF-II in the placenta. This is of interest since 
food-restricted pregnant dams also had reduced placental weights and numbers of foetuses. Previous studies have shown that the placental weight is not the only factor adversely affected by food restriction, but also the placental structure, resulting in an impaired capacity for placental substrate transfer (Roberts et al. 2001a). Interestingly, maternal plasma levels of IGF-II have been shown to be related to structural development of the placenta (Roberts et al. 2001b). Thus, the expression of mRNA for IGF-II in the placenta indicates an important effect on placental size, structure and function and hence foetal growth.

Pregnancy increased the expression of mRNA for IGF-II in the liver and in the parametrial adipose tissue in this study. Apart from the expression of mRNA for IGF-II in the placenta, which has been widely studied (Shen et al. 1986, Reynolds et al. 1997), few studies have investigated how pregnancy affects the expression of mRNA for IGF-II in non-reproductive tissues. The plasma levels of IGF-II were reduced in the pregnant dams as compared with the virginal animals in this study, which is in contrast to findings in a previous study performed in a similar animal model (Sohlström et al. 1998a). The reason for these opposing results is unknown, but may be explained, in part, by the fact that the studies were performed in different strains of guinea pigs.

In conclusion, this study has shown that in guinea pigs, adipose tissue expresses as high amounts of mRNA for IGF-I as the liver, and that this expression is doubled during pregnancy. This indicates an important role for the adipose tissue during gestation, not only as an energy store but also as an autocrine/paracrine as well as an endocrine tissue, both in ad libitum-fed and food-restricted animals. mRNA for IGF-II was expressed at the highest levels in the placenta and liver. The expression in the placenta was reduced by food restriction. It is suggested that the decreased expression of IGF-II in the placenta may have adverse effects on placental size, structure and function.

\section{Acknowledgements}

We thank Professor Hans Arnqvist for kindly letting us use the filtration equipment and Dr Gunilla Dahlfors, Ms Susanne Thunholm, and Dr Kristina Linder for introducing us to the solution hybridisation technique. Furthermore, we thank Dr Phil C Owens for analysing IGF-I and IGF-II in plasma. We are grateful to Ms Pia Fernberg for skillful laboratory assistance.

\section{Funding}

This study was supported by the Åke Wiberg Foundation, the Magnus Bergvall Foundation, and the Tore Nilsson Foundation. There is no conflict of interest among parties concerned.

\section{References}

Bastian SEP, Walton PE, Wallace JC \& Ballard FJ 1993 Plasma clearance and tissue distribution of labelled insulin-like growth factor-1 (IGF-I) and an analogue LR ${ }^{3}$ IGF-I in pregnant rats. Journal of Endocrinology 138 327-336.

Bell GI, Stempien MM, Fong NM \& Seino S 1990 Sequence of a cDNA encoding guinea pig IGF-I. Nucleic Acids Research 18 4275 .

Butler A \& LeRoith D 2001 Control of growth by the somatotropic axis: growth hormone and the insulin-like growth factors have related and independent roles. Annual Reviews of Physiology 63 141-164.

Clemmons DR 1998 Role of insulin-like growth factor binding proteins in controlling IGF actions. Molecular and Cellular Endocrinology 140 19-24.

Cohick WS \& Clemmons DR 1993 The insulin-like growth factors. Annual Reviews of Physiology 55 131-153.

Coleman ME, Russell L \& Etherton TD 1994 Porcine somatotropin $(\mathrm{pST})$ increases IGF-I mRNA abundance in liver and subcutaneous adipose tissue but not in skeletal muscle of growing pigs. Journal of Animal Science 72 918-924.

Conlon MA, Tomas FM, Owens PC, Wallace JC, Howarth GS \& Ballard FJ 1995 Long R ${ }^{3}$ insulin-like growth factor-I (IGF-I) infusion stimulates organ growth but reduces plasma IGF-I, IGF-II and IGF binding protein concentrations in the guinea pig. Journal of Endocrinology 146 247-253.

Correia-Da-Silva G, Bell SC, Pringle JH \& Teixeira N 1999 Expression of mRNA encoding insulin-like growth factors I and II by uterine tissues and placenta during pregnancy in the rat. Molecular Reproduction and Development 53 294-305.

Daughaday WH, Yanow CE \& Kapadia M 1986 Insulin-like growth factors I and II in maternal and fetal guinea pig serum. Endocrinology 119 490-494.

Davenport ML, Svoboda ME, Koerber KL, Van Myk JJ, Clemmons DR \& Underwood LE 1988 Serum concentrations of insulin-like growth factor II are not changed by short term fasting and refeeding. Journal of Clinical Endocrinology and Metabolism 67 1231-1236.

Davies SC, Wass JA, Ross RJ, Cotterill AM, Buchman CR, Coulson VJ \& Holly JM 1991 The induction of a specific protease for insulin-like growth factor binding protein-3 in the circulation during severe illness. Journal of Endocrinology 130 469-473.

Donovan SM, Oh Y, Pham H \& Rosenfeld RG 1989 Ontogeny of serum insulin-like growth factor binding proteins in the rat. Endocrinology 125 2621-2627.

Donovan S, Giudice LC, Murphy LJ, Hintz RL \& Rosenfeld RG 1991 Maternal insulin-like growth factor-binding protein messenger ribonucleic acid during rat pregnancy. Endocrinology 129 3359-3366.

Durnam DM \& Palmiter RD 1983 A practical approach for quantitating specific mRNAs by solution hybridization. Analytical Biochemistry 131 385-393.

Gargosky SE, Moyse KJ, Walton PE, Owens JA, Wallace JC, Robinson JS \& Owens PC 1990 Circulating levels of insulin-like growth factors increase and molecular forms of their serum binding proteins change with human pregnancy. Biochemical and Biophysical Research Communications 170 1157-1163.

Gargosky SE, Owens JA, Walton PE, Owens PC, Wallace JC \& Ballard FJ 1991 Administration of insulin-like growth factor-I, but not growth hormone, increases maternal weight gain in late pregnancy without affecting fetal or placental growth. Journal of Endocrinology 130 395-400.

Hall K, Hansson U, Lundin G, Luthman M, Persson B, Póvoa G, Stangenberg M \& Öfverholm U 1986 Serum levels of 
somatomedins and somatomedin-binding protein in pregnant women with type 1 or gestational diabetes and their infants. Journal of Clinical Endocrinology and Metabolism 63 1300-1306.

Hamilton GS, Lysiak JJ, Han VKM \& Lala PK 1998

Autocrine-paracrine regulation of human trophoblast invasiveness by insulin-like growth factor (IGF)-II and IGF-binding protein (IGFBP)-1. Experimental Cell Research 244 147-156.

Han VKM, Bassett NS, Walton J \& Challis JRG 1996 The expression of insulin-like growth factor (IGF) and IGF-binding protein (IGFBP) genes in the human placenta and membranes: evidence for IGF-IGFBP interactions at the feto-maternal interface. Journal of Clinical Endocrinology and Metabolism 81 2680-2693.

Han VKM, Carter AM, Chandarana S, Tanswell B \& Thompson K 1999 Ontogeny of expression of insulin-like growth factor (IGF) and IGF binding protein mRNAs in the guinea-pig placenta and uterus. Placenta 20 361-377.

Hills FA, English J \& Chard T 1996 Circulating levels of IGF-I and IGF-binding protein-1 throughout pregnancy: relation to birthweight and maternal weight. Journal of Endocrinology 148 303-309.

Holmes RP, Holly JMP \& Soothill PW 1998 A prospective study of maternal serum insulin-like growth factor-I in pregnancies with appropriately grown or growth-restricted fetuses. British Journal of Obstetrics and Gynaecology 105 1273-1278.

Jones JI \& Clemmons DR 1995 Insulin-like growth factors and their binding proteins: biological actions. Endocrine Reviews 16 3-34.

Leaman DW, Simmen FA, Ramsay TG \& White ME 1990 Insulin-like growth factor-I and -II messenger RNA expression in muscle, heart, and liver of streptozotocin-diabetic swine. Endocrinology 126 2850-2857.

Levinovitz A, Norstedt G, van den Berg S, Robinson IC \& Ekström TJ 1992 Isolation of an insulin-like growth factor II cDNA from guinea pig liver: expression and developmental regulation. Molecular and Cellular Endocrinology 89 105-110.

Melton DA, Krieg PA, Rebagliati MR, Maniatis T, Zinn K \& Green MR 1984 Efficient in vitro synthesis of biologically active RNA and RNA hybridization probes from plasmids containing a bacteriophage SP6 promoter. Nucleic Acids Research 12 7035-7056.

Möller C, Arner P, Sonnenfeld T \& Norstedt G 1991 Quantitative comparison of insulin-like growth factor mRNA levels in human and rat tissues analysed by a solution hybridization assay. Journal of Molecular Endocrinology 7 213-222.

Monaco MH \& Donovan SM 1996 Moderate food restriction abolishes the pregnancy-associated rise in serum growth hormone and decreases serum insulin-like growth factor-I (IGF-I) concentrations without altering IGF-I mRNA expression in rats. Journal of Nutrition 126 544-553.

Muaku SM, Beauloye V, Thissen JP, Underwood LE, Ketelslegers JM \& Maiter D 1995 Effects of maternal protein malnutrition on fetal growth, plasma insulin-like growth factors, insulin-like growth factor binding proteins, and liver insulin-like growth factor gene expression in the rat. Pediatric 37 334-342.

Nason KS, Binder ND, Labarta JI, Rosenfeld RG \& Gargosky SE 1996 IGF-II and IGF-binding proteins increase dramatically during rabbit pregnancy. Journal of Endocrinology 148 121-130.

Ohlsson C, Sjögren K, Jansson JO \& Isaksson OGP 2000 The relative importance of endocrine versus autocrine/paracrine insulin-like growth factor-I in the regulation of body growth. Pediatric Nephrology 14 541-543.

Owens JA 1991 Endocrine and substrate control of fetal growth: placental and maternal influences and insulin-like growth factors. Reproduction, Fertility and Development 3 501-517.

Owens PC, Johnson RJ, Campbell RG \& Ballard FJ 1990 Growth hormone increases insulin-like growth factor-I (IGF-I) and decreases IGF-II in plasma of growing pigs. Journal of Endocrinology 124 269-275.
Peter MA, Winterhalter KH, Böni-Schnetzler M, Froesch ER \& Zapf J 1993 Regulation of insulin-like growth factor-I (IGF-I) and IGF-binding proteins by growth hormone in rat white adipose tissue. Endocrinology 133 2624-2631.

Prentice AM, Poppitt SD, Goldberg GR \& Prentice A 1995 Adaptive strategies regulating energy balance in human pregnancy. Human Reproduction Update 1 149-161.

Reynolds TS, Stevenson KR \& Wathes DC 1997 Pregnancy-specific alterations in the expression of the insulin-like growth factor system during early placental development in the ewe. Endocrinology 138 886-897.

Roberts CT, Sohlström A, Kind KL, Earl RA, Khong TY, Robinson JS, Owens PC \& Owens JA 2001a Maternal food restriction reduces the exchange surface area and increases the barrier thickness of the placenta in the guinea-pig. Placenta 22 177-185.

Roberts CT, Sohlström A, Kind KL, Grant PA, Earl RA, Robinson JS, Khong TY, Owens PC \& Owens JA $2001 b$ Altered placental structure induced by maternal food restriction in guinea pigs: a role for circulating IGF-II and IGFBP-2 in the mother? Placenta 22 S77-S82.

Rutanen EM 2000 Insulin-like growth factors in obstetrics. Current Opinion in Obstetrics and Gynecology 12 163-168.

Saintonge J \& Rosso P 1983 Placental blood flow and transfer of nutrient analogues during normal gestation in the guinea pig. Placenta 4 31-40.

Shen S, Wang C, Nelson K, Jansen M \& Ilan J 1986 Expression of insulin-like growth factor II in human placentas from normal and diabetic pregnancies. PNAS 83 9179-9182.

Sjögren K, Liu J-L, Blad K, Skrtic S, Vidal O, Wallenius V, LeRoith D, Törnell J, Isaksson OGP, Jansson J-O \& Ohlsson C 1999 Liver-derived insulin-like growth factor I (IGF-I) is the principal source of IGF-I in blood but is not required for postnatal body growth in mice. PNAS 96 7088-7092.

Sohlström A, Kabir N, Sadurskis A \& Forsum E 1994 Body composition and fat distributrion during the first weeks of gestation in ad lib.-fed and energy-restricted rats. British Journal of Nutrition $\mathbf{7 1}$ 317-333.

Sohlström A, Katsman A, Kind KL, Roberts CT, Owens PC, Robinson JS \& Owens JA 1998a Food restriction alters pregnancyassociated changes in IGF and IGFBP in the guinea pig. American Journal of Physiology 274 E410-E416.

Sohlström A, Katsman A, Kind KL, Grant PA, Owens PC, Robinson JS \& Owens JA 1998b Effects of acute and chronic food restriction on the insulin-like growth factor axis in the guinea pig. Journal of Endocrinology 157 107-114.

Sohlström A, Fernberg P, Owens JA \& Owens PC 2001 Maternal nutrition affects the ability of treatment with IGF-I and IGF-II to increase growth of placenta and the fetus in guinea pigs. Growth Hormone and IGF Research 11 392-398.

Soliman AT, Hassan AE, Aref MK, Hintz RL, Rosenfeld RG \& Rogol AD 1986 Serum insulin-like growth factors-I and -II concentrations and growth hormone and insulin responses to arginine infusion in children with protein-energy malnutrition before and after nutritional rehabilitation. Pediatric Research 20 1122-1130.

Sterle JA, Boyd CK, Peacock JT, Koenigsfeld AT, Lamberson WR, Gerrard DE \& Lucy MC 1998 Insulin-like growth factor (IGF)-I, IGF-II, IGF-binding protein-2 and pregnancy-associated glycoprotein mRNA in pigs with somatotropin-enhanced fetal growth. Journal of Endocrinology 159 441-450.

Straus DS \& Takemoto CD 1991 Specific decrease in liver insulinlike growth factor-I and brain insulin-like growth factor-II gene expression in energy-restricted rats. Journal of Nutrition $\mathbf{1 2 1}$ 1279-1286.

Thissen JP, Ketelslegers JM \& Underwood LE 1994 Nutritional regulation of the insulin-like growth factors. Endocrine Reviews 15 80-101. 
Wabitsch M, Heinze E, Debatin KM \& Blum W 2000 IGF-I and IGFBP-3 expression in cultured human preadipocytes and adipocytes. Hormone and Metabolic Research 32 555-559.

Wilson DM, Bennett A, Adamson GD, Nagashima RJ, Liu F, DeNatale ML, Hintz RL \& Rosenfeld RG 1982 Somatomedins in pregnancy: a cross-sectional study of insulin-like growth factors I and II and somatomedin peptide content in normal human pregnancies. Journal of Clinical Endocrinology and Metabolism $\mathbf{5 5}$ 858-861.

Received in final form 30 July 2003

Accepted 22 August 2003

Made available online as an

Accepted Preprint 2 September 2003 